ISSN 1392-3196 / e-ISSN 2335-8947

Zemdirbyste-Agriculture, vol. 104, No. 3 (2017), p. 235-242

DOI 10.13080/z-a.2017.104.030

\title{
Effect of kiwiberry pre-storage treatments on the fruit quality during cold storage
}

\author{
Jan STEFANIAK, Monika SAWICKA, Tomasz KRUPA, Piotr LATOCHA, \\ Barbara ŁATA \\ Warsaw University of Life Sciences - SGGW \\ Nowoursynowska 159, 02-776 Warsaw, Poland \\ E-mail: barbara_lata@sggw.pl
}

\begin{abstract}
The kiwiberry (Actinidia arguta (Siebold et Zucc.) Planch ex Miq) has become a widely studied species in recent years due to its high resistance to low temperature and high content of health-promoting phytochemicals. The aim of this study was to verify the effect of pre-storage application of oxalic acid, salicylic acid and acetylsalicylic acid, calcium chloride $\left(\mathrm{CaCl}_{2}\right)$ and 1-methlycyclopropene (1-MCP) on quality changes of the kiwiberry cultivar 'Weiki' during cold storage. During six weeks of storage fruit firmness, titratable acidity and the total ascorbate content decreased from an average of $61 \mathrm{~N}, 1.5 \%, 857 \mathrm{mg} \mathrm{kg}^{-1}$ to $2.5 \mathrm{~N}, 1 \%, 380 \mathrm{mg} \mathrm{kg}^{-1}$, respectively. Contrary, the soluble solids and the total phenolics content increased from an average of $0.30 \%, 73.5 \mathrm{mg} \mathrm{kg}^{-1}$ to $0.51 \%$, $172 \mathrm{mg} \mathrm{kg}^{-1}$, respectively. Application of 1-MCP clearly improved fruit firmness and inhibited the ascorbate loss. Compared to the control, the fruit firmness and total ascorbate content was higher by $50 \%$ and $13 \%$, respectively. The acetylsalicylic acid treated fruit exhibited significant drop of phenolics as compared to the control. There was no significant difference in fruit total antioxidant activity determined immediately after harvest and at the end of storage (16.7 vs $17 \mathrm{mmol} \mathrm{kg}^{-1}$, respectively). Fruit treated by salicylic acid, $\mathrm{CaCl}_{2}$ and 1- $\mathrm{MCP}_{\text {was }}$ characterized by a significantly higher titratable acidity compared to the control group. This study showed that the highest ability to maintain fruit quality during cold storage was exhibited by 1-MCP treated kiwiberry.
\end{abstract}

Key words: Actinidia arguta, antioxidant potential, ascorbate, mini kiwi, organic acids, phenolics, postharvest treatments.

\section{Introduction}

Actinidia arguta (Siebold et Zucc.) Planch ex Miq., also known as mini kiwi, kiwiberry, baby kiwi or hardy kiwifruit, names which all refer to small smooth fruit with edible green or red skin, is a promising fruit species, suitable for cultivation in temperate climate (Bieniek et al., 2016). Global commercial production of kiwiberry is continuously increasing (Latocha et al., 2015 b). The yield in 2015 was at least 500 tons (Latocha, Debersaques, 2016). In addition to being considered tasty with the ability to be eaten whole, kiwiberry was reported to contain large amounts of vitamin C, phenolics, carotenoids and some minerals (Nishiyama et al., 2004; 2005; Fisk et al., 2006; Bieniek, Dragańska, 2013; Latocha et al., 2015 a; b). In contrast to kiwifruit, kiwiberry peel can be considered as an additional source of those compounds (Kim et al., 2009; Latocha et al., 2015 b; Wojdyło et al., 2017). Furthermore, A. arguta plants show good winter hardiness as well as short growing and maturation period (Bieniek et al., 2016), hence, it can be grown in temperate climate zone. Apart from the abovedescribed attributes, postharvest storage ability and fruit storage characteristics are of great importance, especially in the case of commercial production. Physiologically mature fruit of $A$. deliciosa cultivar 'Hayward' can be stored under refrigeration for 4-6 months, while the kiwiberry only 1-2 months (Fisk et al., 2006; Krupa et al., 2011; Latocha et al., 2014). Kiwiberry belongs to climacteric fruits in which ethylene speeds up the processes of fruit ripening and softening due to continued fruit respiration, which is accompanied by chlorophyll and starch degradation (Wang et al., 2015 a). Therefore, the application of ethylene action inhibitors is considered to be a promising method for the storage of climacteric fruit. Currently only fragmentary data exist on the effect of 1-MCP and other ethylene release inhibitors on the bioactive compound contents in kiwiberry (Wang et al., 2015 a).

Oxalic, acetylsalicylic and salicylic acids are compounds commonly present in plant tissue. It should be pointed out that as naturally occurring compounds they also satisfy consumer demands with respect to food preservation systems. It was reported that those

Please use the following format when citing the article:

Stefaniak J., Sawicka M., Krupa T., Latocha P., Łata B. 2017. Effect of kiwiberry pre-storage treatments on the fruit quality during cold storage. Zemdirbyste-Agriculture, 104 (3): 235-242 DOI 10.13080/z-a.2017.104.030 
compounds can delay the ripening of climacteric fruits and can improve their postharvest characteristics (Zhang et al., 2003; Valero et al., 2011; Yin et al., 2013; Wang et al., 2015 b). Calcium is also associated with processes which result in lower rates of ethylene production and finally retard ripening. Research on kiwifruit showed that postharvest $\mathrm{CaCl}_{2}$ application prevented flesh firmness loss and peroxidase activity, while decreasing weight loss and fruit softening during cold storage (Kazemi et al., 2011).

However, little is known about changes in kiwiberry chemical composition and quality in relation to different pre-storage fruit treatments. Thus, the aim of this study was to compare the effect of exogenous application of acetylsalicylic (ASA), oxalic (OX) and salicylic (SA) acids, calcium chloride $\left(\mathrm{CaCl}_{2}\right)$ and widely used 1-methlycyclopropene (1-MCP) technique on the kiwiberry quality changes including the content of biologically active compounds as well as total antioxidant activity during cold storage.

\section{Materials and methods}

Material, harvest and storage conditions. Kiwiberry (Actinidia arguta (Siebold et Zucc.) Planch ex Miq.) cultivar 'Weiki' was harvested at commercial maturity stage (7-7.5\% soluble solid content) (Latocha et al., 2014; Lim et al., 2016) from a commercial plot located in Bodzew, Mazowieckie State, Poland $\left(51^{\circ} 47^{\prime} 49.9^{\prime \prime} \mathrm{N}, 20^{\circ} 48^{\prime} 44.0^{\prime \prime} \mathrm{E}\right)$. Fruit of a moderate and equal size, without any deformations or damage, was collected manually from a number of randomly selected plants on the $6^{\text {th }}$ of September, 2014. Based on previous studies (Fattahi et al., 2010; Kazemi et al., 2011; Valero et al., 2011), the following pre-storage treatments were investigated: salicylic acid (SA), acetylsalicylic acid (ASA), oxalic acid (OX) - each of the compounds was used in the concentration of $2 \mathrm{mmol}$, next $2 \%$ calcium chloride $\left(\mathrm{CaCl}_{2}\right)(\mathrm{w} / \mathrm{v}), 0.65 \mu \mathrm{L} \mathrm{L}^{-1}$ 1-methlycyclopropene (1-MCP) and control (distilled water). Solutions were prepared in distilled water. In the control, SA, ASA and OX treatments, fruit was dipped in the solutions for $5 \mathrm{~min}$. The fruit treated with $2 \% \mathrm{CaCl}_{2}$ was dipped for $2 \mathrm{~min}$. Afterwards the fruit was dried at room temperature and packed into plastic punnets of $250 \mathrm{~g}$ capacity. Application of 1-MCP was made on fruit held in storage chambers (volume of one cubic meter). Fruit was gas-treated for $24 \mathrm{~h}$ at 1 -MCP concentration of $665 \mathrm{ppm}$ and temperature of $1^{\circ} \mathrm{C}$. During this time fruit of other treatments was stored in contiguous chamber under the same temperature. Finally, the examined fruit was put into cold storage $\left(1^{\circ} \mathrm{C}\right.$ and $85 \%$ relative humidity) for 6 weeks. Storage chambers were equipped with automatic system "Oxystat 200" (David Bishop Ltd., Holland). The first fruit evaluation was made after 14 days of storage and next fruit was taken out for analysis every 7 days. In each term of measurement batch of fruit (20 fruit per replication, three replications per treatment) was transferred to the laboratory. Ten fruit from replication was used to analyse the basic physicochemical parameters. The other ten fruit was frozen in liquid nitrogen, pulverized to a fine powder and stored in $-80^{\circ} \mathrm{C}$ until analysis of bioactive compounds and total antioxidant activity.

Fruit quality measurements. Fruit firmness. Instron 5542 (USA) with round probe $4.5 \mathrm{~mm}$ diameter at $4 \mathrm{~mm} \mathrm{~s}^{-1}$ speed of compression was used to determine the fruit firmness. Assessments were performed on two opposite sides of each fruit. The results were expressed as maximum force to penetrate fruit to the depth of $8 \mathrm{~mm}$ in Newton (N). Fruit previously used for fruit firmness evaluation was homogenized and centrifuged at $5000 \mathrm{rpm}$ and the supernatant was used for analyses of titratable acidity and soluble solid content. The soluble solid content was measured with the digital refractometer PR-32 $\alpha$ (Atago, Japan). The results were expressed as \% soluble solid content. The easy intelligent titrator TitroLine (SI Analytics GmbH, Germany) was used to measure titratable acidity. The kiwiberry juice (supernatant) was diluted with distilled water in the proportion 1:10 (v:v). The juice solution was then titrated with $0.1 \mathrm{M} \mathrm{NaOH}$ up to a $\mathrm{pH}$ value of 8.1 and expressed as citric acid equivalent (\%).

Skin colour was measured on two opposite sides with a colorimeter CR-508i (Minolta, Japan), equipped with a $5 \mathrm{~mm}$ measuring head and observer $10^{\circ}$ and illuminant D65. The meter was calibrated using the manufacturer's standard white plate. Colour changes were quantified in the $\mathrm{L}^{*}, \mathrm{a}^{*}$ and $\mathrm{b}^{*}$ colour space. Hue angle $\left(h^{\circ}\right)$ was calculated from $\mathrm{a}^{*}$ and $\mathrm{b}^{*}$ values:

$$
h^{\circ}=\operatorname{tg}^{-1}\left(\frac{\mathrm{b}^{*}}{\mathrm{a}^{*}}\right)+180^{\circ}, \text { when } \mathrm{a}^{*}<0 \text { and } \mathrm{b}^{*}>0 \text {, }
$$

as well as chroma values: $\left(C=\sqrt{\mathrm{a}^{* 2}+\mathrm{b}^{* 2}}\right)$.

Hue values refer to a colour wheel. Red, yellow, green and blue colours were at an angle of $0^{\circ}, 60^{\circ}, 120^{\circ}$ and $240^{\circ}$, respectively. Chroma describes the vividness or dullness of fruit colour and is also known as colour saturation.

Bioactive compounds and total antioxidant activity measurements. The total ascorbate content (tASC: the sum of L-AA and DHAA, reduced and oxidized forms, respectively) was measured using HPLC technique (Latocha et al., 2015 b). The powdered fruit tissue was suspended in $0.1 \mathrm{M} \mathrm{HCl}$ in a $1: 30(\mathrm{~m} / \mathrm{v})$ ratio. Next, samples were centrifuged at $14000 \mathrm{rpm}$ for $20 \mathrm{~min}$ at $4{ }^{\circ} \mathrm{C}$. The obtained extract was used for tASC determination. The tASC was measured after the complete oxidation of L-AA to DHAA with ascorbate oxidase. DHAA was then derivatized with o-phenylenediamine. The reaction product was detected fluorometrically at $450 \mathrm{~nm}$ by excitation at $350 \mathrm{~nm}$. Separation was made on a Spherisorb ${ }^{\mathrm{R}}$ column $(250 \times 4.6 \mathrm{~mm}, 5 \mu \mathrm{m}$, Waters $)$ by applying a solution of $20 \%$ methanol containing $800 \mathrm{mM} \mathrm{K}_{2} \mathrm{HPO}_{4}(\mathrm{pH}=7.8$ ), flow rate was $1 \mathrm{~mL} \mathrm{~min}^{-1}$. The tASC was quantified using a calibration curve of L-ascorbic acid.

Total phenolics content was evaluated using the new method: Fast Blue BB (FBBB) procedure described by Medina (2011). Two-step extraction in ultrasonic bath was applied. The powdered fruit samples were extracted with $2.5 \mathrm{~mL}$ of $70 \%$ ethanol in a $1: 10(\mathrm{~m} / \mathrm{v})$ ratio in ultrasonic bath for $30 \mathrm{~min}$ and centrifuged at $20000 \mathrm{rpm}$ for $10 \mathrm{~min}$ at $4^{\circ} \mathrm{C}$. The supernatant was decanted and transferred to glass tubes. The residue was extracted again with another $2.5 \mathrm{~mL}$ of $70 \%$ ethanol in the same conditions as described above. Next, the both extracts were combined, centrifuged (20000 rpm, $10 \mathrm{~min}, 4^{\circ} \mathrm{C}$ ), decanted to the Eppendorf tubes and stored in $-20^{\circ} \mathrm{C}$. Before measurement, the extracts were diluted with redistilled water in a $1: 10(\mathrm{v} / \mathrm{v})$ ratio. FBBB reagent created coloured (blue) azo-complexes with phenolic compounds, which were detected spectrophotometrically 
at $420 \mathrm{~nm}$. The results were calculated using a calibration curve and expressed in gallic acid equivalents (GAE).

The FRAP-assay, referred to as total antioxidant activity, is a method based on the reduction of $\mathrm{Fe}^{3+}-\mathrm{TPTZ}$ (4,6-tri(pyridil-S-triazine) to a blue coloured $\mathrm{Fe}^{2+}-\mathrm{TPTZ}$ compound in the presence of antioxidants, which is revealed as a change of absorbance at $593 \mathrm{~nm}$ (Latocha et al., $2015 \mathrm{~b}$ ). Samples were extracted with $5 \mathrm{~mL}$ of MiliQ water in a 1:10 (m/v) ratio and centrifuged at $14000 \mathrm{rpm}$ for 30 seconds. The obtained extract was filtered and the supernatant (diluted with MiliQ water in a 1:2 (v/v) ratio) was added to FRAP reagent containing $10 \mathrm{mM}$ TPTZ in $40 \mathrm{mM} \mathrm{HCl}, 20 \mathrm{mM} \mathrm{FeCl}_{3}$ and $300 \mathrm{mM}$ acetate buffer $(\mathrm{pH}=3.6)$ in the ratio of $1: 1: 10$. The $\mathrm{FeSO}_{4}$ compound was used to prepare the standard solutions.

Statistical analysis and presentation of the data. The obtained results were elaborated by two-way factorial analysis of variance (ANOVA) using software Statgraphics Plus 4.1 (USA). The significance of the differences between means of main effects (storage time and fruit pre-storage treatment) was evaluated using Tukey's honestly significant difference (HSD) procedure, at $5 \%$ probability level. Therefore, the results were presented as mean figures with an indication of homological groups.

\section{Results and discussion}

Influence of fruit pre-storage treatment and time of storage on overall fruit quality. The fruit firmness loss is a physiological process that occurs during ripening, directly affecting postharvest life and the commercial value of different fruits. Short storability is a major problem for the kiwiberry industry, as the fruit firmness drops significantly during storage (Krupa et al., 2011). In this study, the fruit firmness was the only parameter for which the interaction between the main effects was significant (Table). After two weeks of storage fruit firmness of 1-MCP treated fruit was $43.7 \mathrm{~N}$, while for the control group it was $11.7 \mathrm{~N}$. Until the $4^{\text {th }}$ week of storage, application of 1-MCP delayed the process of firmness loss considerably as compared to other treatments. The difference between 1-MCP and other treatments (based on their average fruit firmness values) reduced with time - from being $241 \%$ higher at $2^{\text {nd }}$ week of storage to a $70 \%$ higher at $6^{\text {th }}$ week of storage. Similarly, significant influence of 1-MCP on the fruit firmness of kiwiberry was recently described by Wang et al. (2015 a). In turn, in kiwifruit a delay of its softening during storage in $20^{\circ} \mathrm{C}$ was observed after SA application (Zhang et al., 2003). In other studies, the maintenance of $A$. deliciosa fruit firmness was achieved when fruit was immersed in $\mathrm{CaCl}_{2}$ solution for 1 and 5 minutes, respectively (Kazemi et al., 2011). Discriminants that influence the fruit taste in terms of quality and consumer acceptability are soluble solid content and titratable acidity.

During the first two weeks of storage, soluble solid content in fruit samples almost doubled (Fig. 1A). A smaller, but still significant, constant increase during the next two weeks was observed. Fruit from $4^{\text {th }}$ to $5^{\text {th }}$ week of storage showed the same soluble solid content, but near the end of storage period this quality parameter increased significantly again. There was no substantial influence of pre-storage treatments on soluble solid content (Fig. 1B). In this study, the soluble solid content and titratable acidity changes during storage were similar to those reported by Krupa et al. (2011). Summing up, this parameter decreased by approximately $54 \%$ during examined storage period (Fig. 1C). There was no significant difference between application of the ASA or OX compared to the control. In contrast, the SA, $\mathrm{CaCl}_{2}$ and 1-MCP treated fruit was characterized by a significantly higher values of titratable acidity compared to control group (Fig. 1D). Kazemi et al. (2011) reported that postharvest $\mathrm{CaCl}_{2}$ dips did not affect the titratable acidity in kiwifruit cultivar 'Hayward', while kiwifruit treated with SA solution achieved higher titratable

Table. Effect of treatment and time of storage on Actinidia arguta fruit firmness

\begin{tabular}{cccccccc}
\hline $\begin{array}{c}\text { Pre-storage } \\
\text { treatment } \\
(\mathrm{B})\end{array}$ & 0 & $2^{\text {nd }}$ & $3^{\text {rd }}$ & $4^{\text {th }}$ & $5^{\text {th }}$ & $6^{\text {th }}$ & $\begin{array}{c}\text { Average } \\
(\mathrm{B})\end{array}$ \\
\cline { 2 - 7 } & $61.0^{1} \pm 2.0$ & $11.7 \pm 0.9$ & $5.2 \pm 0.2$ & $3.2 \pm 0.2$ & $2.9 \pm 0.3$ & $2.1 \pm 0.2$ & $14.4 \mathrm{a}$ \\
$\mathrm{Control}$ & $61.0 \pm 2.0$ & $13.9 \pm 1.1$ & $5.8 \pm 0.3$ & $3.4 \pm 0.1$ & $2.9 \pm 0.5$ & $2.2 \pm 0.4$ & $14.9 \mathrm{a}$ \\
$\mathrm{ASA}$ & $61.0 \pm 2.0$ & $13.0 \pm 0.4$ & $5.2 \pm 0.4$ & $4.1 \pm 0.2$ & $3.0 \pm 0.1$ & $2.2 \pm 0.2$ & $14.7 \mathrm{a}$ \\
$\mathrm{SA}$ & $61.0 \pm 2.0$ & $13.1 \pm 0.7$ & $5.3 \pm 0.2$ & $3.2 \pm 0.4$ & $2.8 \pm 0.1$ & $2.4 \pm 0.2$ & $14.6 \mathrm{a}$ \\
$\mathrm{OX}$ & $61.0 \pm 2.0$ & $12.2 \pm 0.9$ & $5.3 \pm 0.3$ & $3.6 \pm 0.1$ & $3.1 \pm 0.5$ & $2.2 \pm 0.1$ & $14.6 \mathrm{a}$ \\
$\mathrm{CaCl}_{2}$ & $61.0 \pm 2.0$ & $43.7 \pm 2.5$ & $10.4 \pm 0.4$ & $6.4 \pm 0.1$ & $4.7 \pm 0.1$ & $3.8 \pm 0.6$ & $21.7 \mathrm{~b}$ \\
$1-\mathrm{MCP}$ & $61.0 \mathrm{e}$ & $17.9 \mathrm{~d}$ & $6.2 \mathrm{c}$ & $4.0 \mathrm{~b}$ & $3.2 \mathrm{ab}$ & $2.5 \mathrm{a}$ & \\
Average (A) & & &
\end{tabular}

Notes. ASA - acetylsalicylic acid, $\mathrm{SA}$ - salicylic acid, $\mathrm{OX}$ - oxalic acid, $\mathrm{CaCl}_{2}$ - calcium chloride, 1-MCP - 1-methylcyclopropene. The values are means of three replications, \pm SD. Values in the row (means for consecutive storage times) or column (means for pre-storage fruit treatment) marked with different letter differ significantly at $P \leq 0.05$ (Tukey HSD test).

acidity and lower soluble solid content than control fruit or those treated with $\mathrm{CaCl}_{2}$. In turn, a significant delaying effect of all analysed compounds (SA, ASA and OA) on the titratable acidity and soluble solid content in sweet cherry fruit was recently described (Valero et al., 2011). Hue and chroma values considerably decreased during storage, indicating a great loss of colour intensity (Fig. 1E, $1 \mathrm{G})$. Compared to the results obtained after harvest a significant decrease of chroma occurred after two weeks of fruit storage (Fig. 1G), while hue angle after 4 weeks of storage (Fig. 1E). Hue values declined more gradually than chroma, which dropped more rapidly. Hue angle remained on the same level regardless of pre-storage treatment (Fig. 1F) while the $\mathrm{CaCl}_{2}$ treated fruit had a significantly higher chroma values as compared to the control, OX and ASA treatments (Fig. 1H). Although the decrease of hue and chroma values was clearly visible during fruit storage, there were no significant effects of examined treatments on the fruit colour changes in this study. Only the use of $\mathrm{CaCl}_{2}$ favoured a higher green colour saturation of the kiwiberry peel. Whereas the positive influence of 1-MCP treatment on pulp colour of kiwifruit was described by Boquete et al. (2004). 

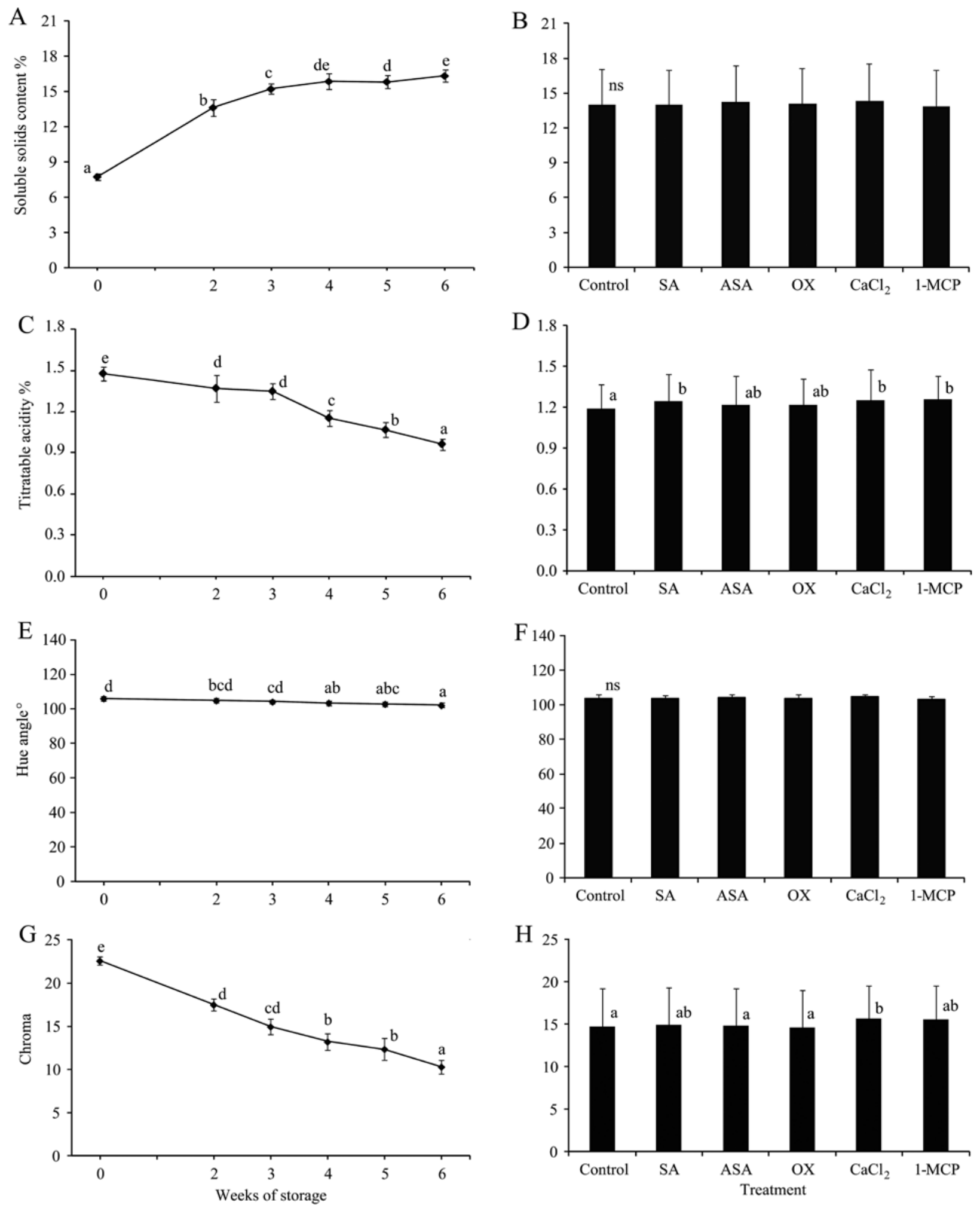

Notes. SA - salicylic acid, ASA - acetylsalicylic acid, $\mathrm{OX}$ - oxalic acid, $\mathrm{CaCl}_{2}$ - calcium chloride, 1-MCP - 1-methylcyclopropene. The values are means obtained for a given level of main effects (weeks of storage or fruit pre-storage treatment), $\pm \mathrm{SD}$. Values marked with different letters differ significantly at $P \leq 0.05$ (Tukey HSD test); ns - not significant.

Figure 1. Effect of storage time (A, C, E, G) and treatment (B, D, F, H) on soluble solids content, titratable acidity and skin colour (hue angle and chroma) in Actinidia arguta fruit

The tASC and total phenolics content contents and total antioxidant activity (FRAP-assay): the effect of storage time and fruit pre-storage treatment. Actinidia genus is described as a rich source of biologically active compounds (Nishiyama et al., 2004; 2005; Latocha et al., 2015 b). Maintaining or enhancing fruit internal quality is the second, after storability potential, important issue in relation to post-harvest fruit management (Fisk et al., 2006; Xia et al., 2016). The extent of fluctuations in the content of phytochemicals during storage depends not only on the storage conditions and pre-storage treatment, but also chemical nature of the compounds and fruit type 
(Łata, 2008; Rapisarda et al., 2008). A general agreement among researchers exists, that fruit phenolic metabolism remains relatively low during long-term storage whereas ascorbic acid is more sensitive to degradation due to its high oxidative capability during food storage or other postharvest treatments (Kevers et al., 2007; Łata, 2008). However, looking through individual studies, the pattern of these compounds changes during storage and shelf life might be sometimes variable and contradictory (Kalt, 2005; Amodio et al., 2007; Jhalegar et al., 2011). The kiwiberry tASC after harvest was measured as $857 \mathrm{mg} \mathrm{kg}^{-1}$ fresh weight and its concentration decreased significantly during storage regardless of treatment type (Fig. 2A). At the end of experiment the tASC was from 1.6 to 2.62 times lower for 1-MCP and control fruit as compared to harvest, respectively (data not shown). Decrease in vitamin $\mathrm{C}$ content in $A$. arguta fruit during 42 days of cold storage was also reported by Krupa et al. (2011). In contrast, Kazemi et al. (2011) described that ascorbic acid
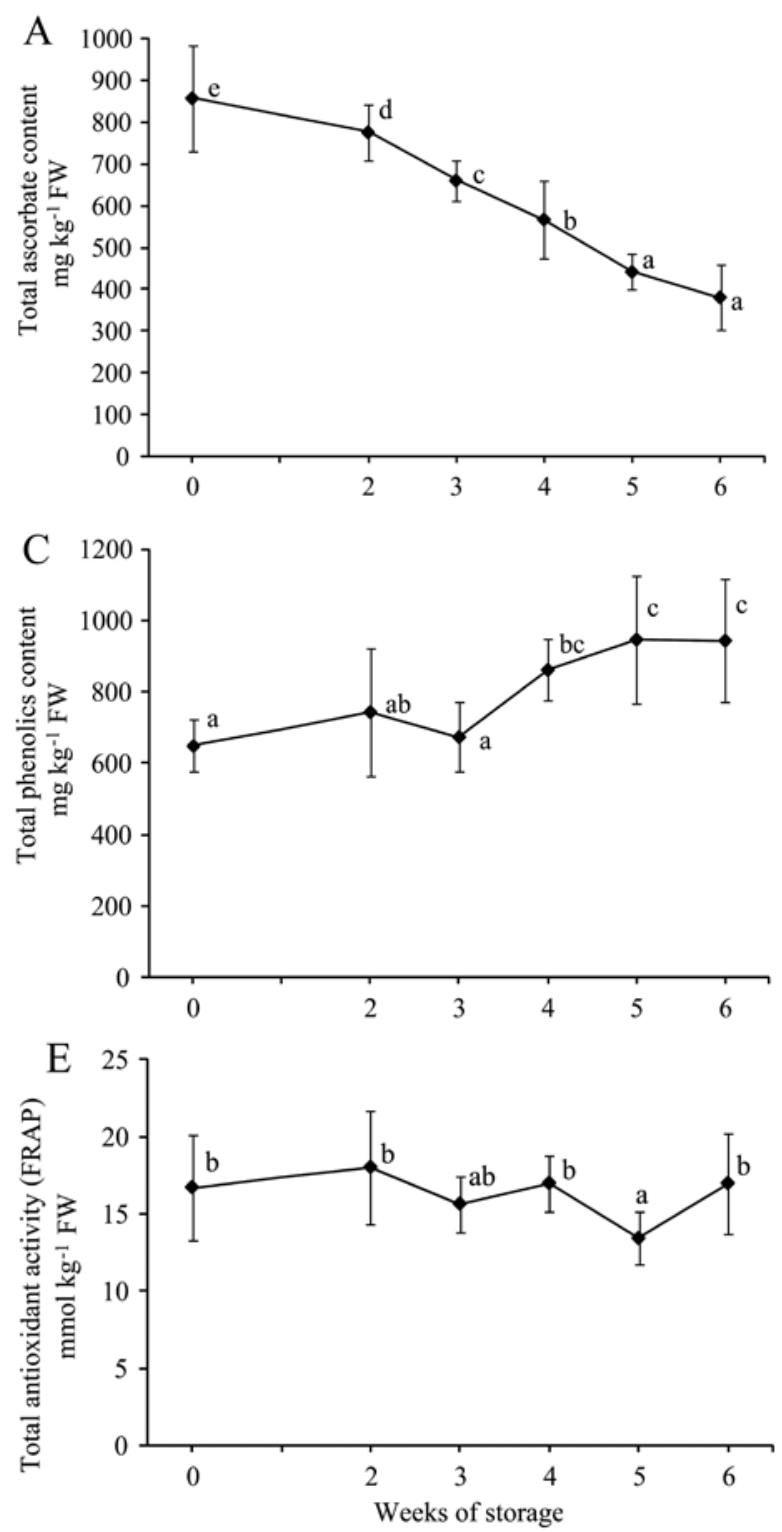

level in A. deliciosa fruit increased during two months of storage at $1{ }^{\circ} \mathrm{C}$, and the $\mathrm{SA}$ and $\mathrm{CaCl}_{2}$ treated fruit showed significantly higher concentration of vitamin $\mathrm{C}$ compared to the control. In our study, compared to the control, tASC losses were significantly reduced after 1-MCP treatment (Fig. 2B). However, according to Vilaplana et al. (2006) ascorbate pathway is not ethylene dependent and therefore 1-MCP treatment should not affect considerably ascorbate status. Besides 1-MCP, some positive effect on tASC occurred after application of $\mathrm{OX}$ and $\mathrm{CaCl}_{2}$ compounds. Other than having high vitamin $\mathrm{C}$ content, kiwiberry is also considered as a rich source of phenolic compounds, richer than that of commonly eaten kiwifruit or apple (Kim et al., 2009). In general, total phenolics content successively increased during storage (Fig. 2C). After the first three weeks of storage the total phenolics content was similar to that obtained after harvest. Especially high increase of total phenolics content was noted after four weeks of cold storage. At the $5^{\text {th }}$ week, the rate of total
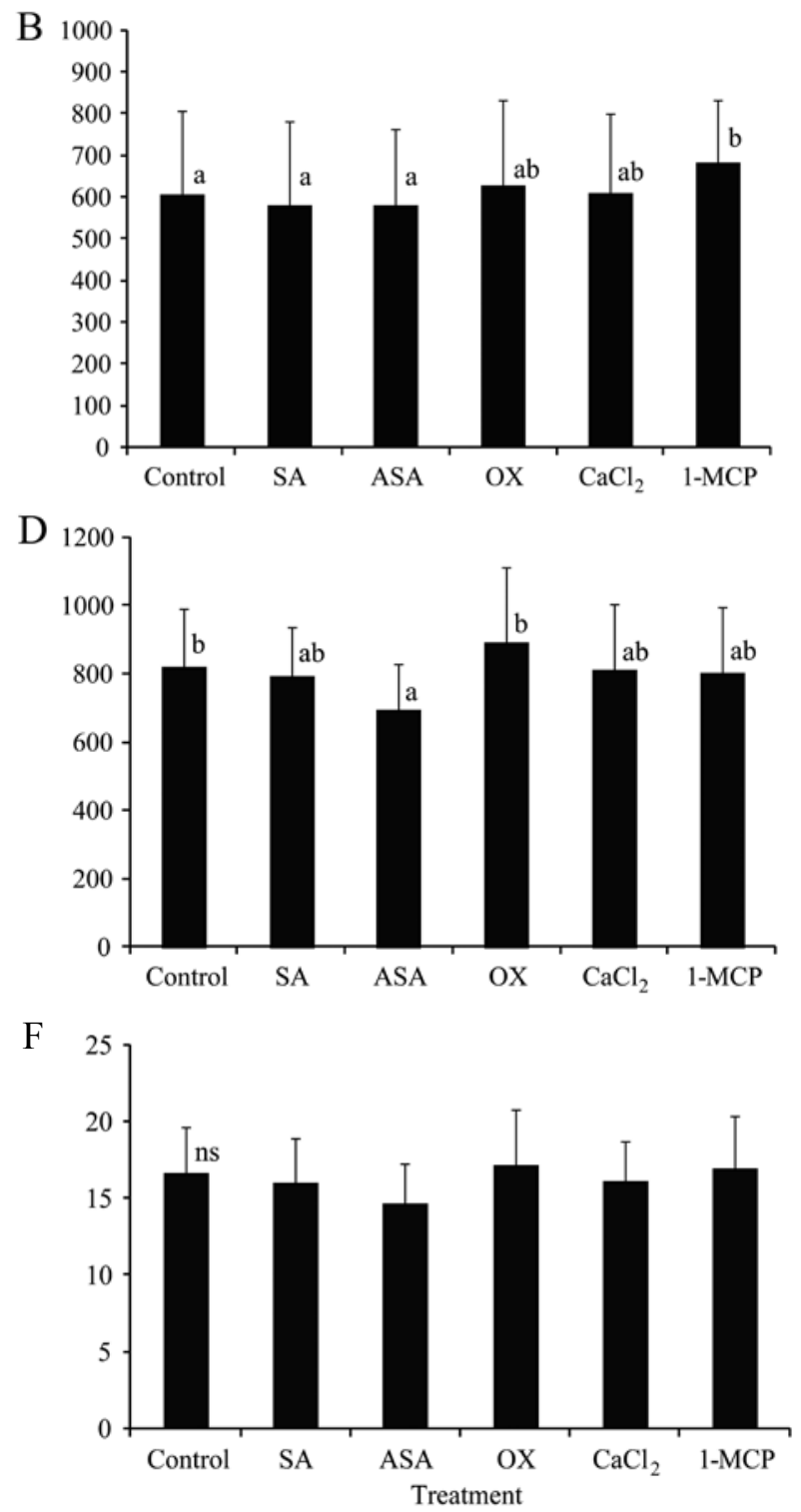

Notes. SA - salicylic acid, ASA - acetylsalicylic acid, $\mathrm{OX}$ - oxalic acid, $\mathrm{CaCl}_{2}$ - calcium chloride, 1-MCP - 1-methylcyclopropene. The values are means obtained for a given level of main effects (weks of storage or fruit pre-storage treatment), $\pm \mathrm{SD}$. Values marked with different letters differ significantly at $P \leq 0.05$ (Tukey HSD test); ns - not significant.

Figure 2. Effect of storage time (A, C, E) and treatment (B, D, F) on the total ascorbate content (tASC), total phenolics content and total antioxidant activity (FRAP-assay) in fresh weight of Actinidia arguta fruit 
phenolics content increase however started to reduce. The total phenolics content after the 4 and 5 weeks of storage was approximately $46 \%$ higher compared to the content at harvest time. The above-described general picture of total phenolics content changes was nearly the same for all treatments up to the $4^{\text {th }}$ week. After that time, fluctuations in total phenolics content were more treatment dependent. It was noted that the type of the fruit pre-storage treatment influenced total phenolics content to a lesser degree than storage time (Fig. 2D). There is a possibility that some biochemical changes in fruit could occur in part due to transpiration of moisture during storage; however, no more than $2.3 \%$ of fruit mass was lost due to transpiration after 6 weeks of storage (data not shown). The increase of total phenolics content up to 35 days of storage was also observed by Amodio et al. (2007) in kiwifruit. Zorić et al. (2017) noted that anthocyanins were more susceptible to degradation compared to other phenolic compounds in stored fruit. Recently, twenty one different phenolic compounds were detected and identified in A. arguta cultivar 'Weiki' fruit by Wojdyło et al. (2017), including flavonols, phenolic acids and anthocyanins. The total phenolics content was reported as $3691 \mathrm{mg}$ $100 \mathrm{~g}^{-1}$ dry weight. Authors stated that in A. arguta fruit anthocyanins present a very marginal percent of all phenolic compounds (Wojdyło et al., 2017). Valero et al. (2011) suggested that some increase in phenolics and anthocyanins concentrations during storage period is due to the postharvest ripening process. An increase in anthocyanins, flavanones and hydroxycinnamic acids and a slight decrease in vitamin $\mathrm{C}$ in the blood oranges during storage was noted (Rapisarda et al., 2008). In turn, cold storage negatively affected flavanone concentration. Other study (Halbwirth et al., 2006) demonstrated that the selected enzymes from the flavonoid pathway that affect flavonoid biosynthesis show two distinct activity peaks during fruit ripening at early and late developmental stages. The first activity peak corresponds to the formation of flavanols, while the second peak is clearly related to anthocyanin and flavonol accumulation.

However, contrary to our study, a gradual decrease of total phenolics content in kiwifruit during 5 weeks of cold $\left(1^{\circ} \mathrm{C}\right)$ storage after $1-\mathrm{MCP}$ treatment was reported by Lim et al. (2016). Krupa et al. (2011) also noted decreasing total phenolics content levels during cold storage in $A$. arguta fruit but with no pre-storage treatment. Liu et al. (2015) reported that 1-MCP could delay or reduce the total phenolics content accumulation in peaches, which is in agreement with studies on avocados (Zhang et al., 2013). In this study, as compared to the control and other treatments, no particular effect of 1-MCP on total phenolics content was noted. The highest total phenolics content was noted in fruit after prestorage OX application. Moreover, fruit treated by ASA was characterized be a significantly lower total phenolics content as compared to the control. Results recently obtained by Zhu et al. (2016) were promising in relation to OX application. Authors stated that the OX treatment increased quality and induced disease resistance in kiwifruit. Summing up, it is difficult to outline a clear pattern of phenolic changes, phenol content may either increase or decrease depending on the species, the storage conditions or fruit postharvest (pre-storage) treatment.

Ascorbate and phenolics as well as other antioxidants contribute to the overall fruit total antioxidant activity. There were no significant differences between total antioxidant activity determined immediately after harvest and at the end of fruit storage (Fig. 2E). However, it should be added that between these two extreme point of measurements, in sequence, increases $\left(2^{\text {nd }}, 4^{\text {th }}\right.$ and $6^{\text {th }}$ week) and decreases ( $3^{\text {rd }}$ and $5^{\text {th }}$ week) of the total antioxidant activity, compared to harvest time, were noted. The highest drop of fruit total antioxidant activity was measured between $4^{\text {th }}$ and $5^{\text {th }}$ week. Compared to the second week, in which FRAP value was the highest during kiwiberry storage, the total antioxidant activity after 5 weeks of storage decreased by $34 \%$. The examined treatments did not differ significantly in total antioxidant activity (Fig. 2F). Shivashankara et al. (2004) suggested that an increase in antioxidant capacity during cold storage may be possible only in fruit in which the contribution of total phenolics to total antioxidant activity is greater than that of the ascorbic acid. Tavarini et al. (2008) reported the correlation studies on antioxidants and phytochemical constituents responsible for antioxidant capacity in kiwifruits. Authors suggested that in kiwifruits vitamin $\mathrm{C}$ contributed to antioxidant capacity much more than other antioxidant constituents (phenols or carotenoids). However, in Actinidia genus a decrease (Tavarini et al., 2008; Krupa et al., 2011) or an increase (Amodio et al., 2007; Buccheri et al., 2015) of total antioxidant activity during cold storage was noted. The above mentioned inconsistency might be caused by various content and behaviour of individual bioactive compounds during storage and some differences in storage conditions or the way of measurement of total antioxidant activity (Lata, 2008). In our study, the total antioxidant activity could have remained almost unchanged probably because of a simultaneous rise of the total phenolics content and significant decrease of the tASC.

\section{Conclusions}

1. According to our study, 1-methlycyclopropene (1-MCP) postharvest treatment had significant effect on kiwiberry (Actinidia arguta) ripening, manifesting itself by delaying the decline in fruit firmness and retarding the increase of soluble solids content.-

2. 1-MCP as well as calcium chloride $\left(\mathrm{CaCl}_{2}\right)$ and salicylic acid (SA) significantly delayed the decrease in the titratable acidity compared to the control.

3. Regardless of the postharvest treatment method used, total phenolics content considerably increased but total ascorbate content (tASC) significantly decreased during cold storage.

4. The pre-storage treatment with acetylsalicylic acid (ASA) significantly reduced the total phenolics content in kiwiberry fruit. In turn, oxalic acid (OX) application apparently, but not significantly, increased the phenolics content.

5. Application of 1-MPC, followed by $\mathrm{OX}$ and $\mathrm{CaCl}_{2}$ maintained the kiwiberry vitamin $\mathrm{C}$ content at the highest level during cold storage.

6. The examined treatments did not have significant influence on the total antioxidant activity of kiwiberry.

7. The possible solutions to improve quality characteristics during storage may involve combining treatment methods, changing treatment times or changing concentration of applied compounds.

Received 21122016 Accepted 08052017 


\section{References}

1. Amodio M. L., Colelli G., Hasey J. K., Kader A. A. 2007. A comparative study of composition and postharvest performance of organically and conventionally grown kiwifruits. Journal of the Science of Food and Agriculture, 87: 1228-1236. https://doi.org/10.1002/jsfa.2820

2. Bieniek A., Dragańska E. 2013. Content of macroelements in fruits of Ukrainian cultivars of hardy kiwifruit and Actinidia charta depending on the weather conditions during the phenological phases. Journal of Elementology, 18 (1): 23-28.

3. Bieniek A., Dragańska E., Pranckietis V. 2016. Assesment of climatic conditions for Actinidia arguta cultivation in north-eastern Poland. Zemdirbyste-Agriculture, 103 (3): 311-318. https://doi.org/10.13080/z-a.2016.103.040

4. Boquete E. J., Trinchero G. D., Fraschina A. A., Videllam F. Sozzi G. O. 2004. Ripening of 'Hayward' kiwifruit treated with 1-methylcyclopropene after cold storage. Postharvest Biology and Technology, 32 (1): 57-65.

https://doi.org/10.1016/j.postharvbio.2003.09.013

5. Buccheri M., D’Ambrosio T., Grassi M., Caralla A. 2015. Chemical composition and antioxidant activity of Actinidia fruits after postharvest ripening. Acta Horticulturae, 1079 (83): 611-617. https://doi.org/10.17660/ActaHortic.2015.1079.83

6. Fattahi J., Fifaii R., Babri M. 2010. Postharvest quality of kiwifruit (Actinidia deliciosa cv. Hayward) affected by prestorage application of salicylic acid. South-Western Journal of Horticulture, Biology and Environment, 1 (2): 175-186.

7. Fisk C. L., Mc Daniel M. R., Strik B. C., Zhao Y. 2006. Physicochemical, sensory, and nutritive qualities of hardy kiwifruit (Actinidia arguta 'Ananasnaya') as affected by harvest maturity and storage. Journal of Food Science, 71 (3): 204-210.

https://doi.org/10.1111/j.1365-2621.2006.tb15642.x

8. Halbwirth H., Puhl I., Haas U., Jezik K., Treutter D., Stich K. 2006. Two-phase flavonoid formation in developing strawberry (Fragaria $\times$ ananassa) fruit. Journal of Agricultural and Food Chemistry, 54 (4): 1479-1485. https://doi.org/10.1021/jf0524170

9. Jhalegar J., Sharma R. R., Pal R. K., Arora A., Dahuja A. 2011. Analysis of physiological and biochemical changes in kiwifruit (Actinidia deliciosa cv. Allison) after the postharvest treatment with 1-methylcyclopropene. Journal of Plant Biochemistry and Biotechnology, 20 (2): 205-210. https://doi.org/10.1007/s13562-011-0047-4

10. Kalt W. 2005. Effects of production and processing factors on major fruits and vegetable antioxidants. Journal of Food Science, 70: 11-19. https://doi.org/10.1111/j.1365-2621.2005.tb09053.x

11. Kazemi M., Aran M., Zamani S. 2011. Effect of calcium chloride and salicylic acid treatments on quality characteristics of kiwifruit (Actinidia deliciosa cv. Hayward) during storage. American Journal of Plant Physiology, 6 (3): 183-189. https://doi.org/10.3923/ajpp.2011.183.189

12. Kevers C., Falkowski M., Tabart J., Defraigne J. O., Dommes J., Pincemail J. 2007. Evolution of antioxidant capacity during storage of selected fruits and vegetables. Journal of Agricultural and Food Chemistry, 55 (21): 85968603. https://doi.org/10.1021/jf071736j

13. Kim G. J., Beppu K., Kataoka I. 2009. Varietal differences in phenolic content and astringency in skin and flesh of hardy kiwifruit resources in Japan. Scientia Horticulturae, 120 (4): 551-554. https://doi.org/10.1016/j.scienta.2008.11.032

14. Krupa T., Latocha P., Liwińska A. 2011. Changes of physicochemical quality, phenolics and vitamin $\mathrm{C}$ content in hardy kiwifruit (Actinidia arguta and its hybrid) during storage. Scientia Horticulturae, 130 (2): 410-417. https://doi.org/10.1016/j.scienta.2011.06.044
15. Łata B. 2008. Apple peel antioxidant status in relation to genotype, storage type and time. Scientia Horticulturae, 117 (1): 45-52. https://doi.org/10.1016/j.scienta.2008.03.011

16. Latocha P., Krupa T., Jankowski P., Radzanowska J. 2014. Changes in postharvest physicochemical and sensory characteristics of hardy kiwifruit (Actinidia arguta and its hybrid) after cold storage under normal versus controlled atmosphere. Postharvest Biology and Technology, 88: 21-33. https://doi.org/10.1016/j.postharvbio.2013.09.005

17. Latocha P., Debersaques F., Decorte J. 2015 (a). Varietal difference in the mineral composition of kiwiberry Actinidia arguta (Siebold et Zucc.) Planch. ex Miq. Acta Horticulturae, 1096: 479-486.

https://doi.org/10.17660/ActaHortic.2015.1096.59

18. Latocha P., Łata B., Stasiak A. 2015 (b). Phenolics, ascorbate and the antioxidant potential of kiwiberry $v s$. common kiwifruit: the effect of cultivar and tissue type. Journal of Functional Foods, 19: 155-163. https://doi.org/10.1016/j.jff.2015.09.024

19. Latocha P., Debersaques F. 2016. The global production and market of kiwiberry. Truskawka, malina, jagody, 1: 32-33 $<$ https://www.plantpress.pl/produkt/truskawka-malinajagody-12016/> (in Polish).

20. Lim S., Ha S. H., Kim J., Lee H. J., Lee J. G., Lee E. J. 2016. Inhibition of hardy kiwifruit (Actinidia arguta) ripening by 1-methylcyclopropene during cold storage and anticancer properties of the fruit extract. Food Chemistry, 190: 150-157. https://doi.org/10.1016/j.foodchem.2015.05.085

21. Liu H., Cao J., Jiang W. 2015. Changes in phenolics and antioxidant property of peach fruit during ripening and responses to 1-methylcyclopropene. Postharvest Biology and Technology, 108: 111-118. https://doi.org/10.1016/j.postharvbio.2015.06.012

22. Medina M. B. 2011. Determination of the total phenolics in juices and superfruits by a novel chemical method. Journal of Functional Foods, 3 (2): 79-87. https://doi.org/10.1016/j.jff.2011.02.007

23. Nishiyama I., Yamashita Y., Yamanaka M., Shimohashi A., Fukuda T., Oota T. 2004. Varietal difference in vitamin C content in the fruit of kiwifruit and other Actinidia species. Journal of Agricultural and Food Chemistry, 52 (17): 5472-5475. https://doi.org/10.1021/jf049398z

24. Nishiyama I., Fukuda T., Oota T. 2005. Genotypic differences in chlorophyll, lutein and $\beta$-carotene content in the fruit of Actinidia species. Journal of Agricultural and Food Chemistry, 53 (16): 6403-6407. https://doi.org/10.1021/jf050785y

25. Rapisarda P., Lo Bianco M., Pannuzzo P., Timpanaro N. 2008. Effect of cold storage on vitamin C, phenolics and antioxidant activity of five orange genotypes (Citrus sinensis (L.) Osbeck). Postharvest Biology and Technology, 49 (3): 348-354. https://doi.org/10.1016/j.postharvbio.2008.02.002

26. Shivashankara K. S., Isobe S., Al-Haq M. I., Takenaka M., Shina T. 2004. Fruit antioxidant activity, ascorbic acid, total phenol, quercitin, and carotene of Irwin mango fruits stored at low-temperature after high electric field treatment. Journal of Agricultural and Food Chemistry, 52 (5): 12811286. https://doi.org/10.1021/jf0302431

27. Tavarini S., Degl'Innocenti E., Remorini D., Massai R., Guidi L. 2008. Antioxidant capacity, ascorbic acid, total phenols and carotenoids changes during harvest and after storage of Hayward kiwifruit. Food Chemistry, 107: 282288. https://doi.org/10.1016/j.foodchem.2007.08.015

28. Valero D., Diaz-Mula H. M., Zapata P. J., Castillo S., Guillén F., Martinez-Romero D., Serrano M. 2011. Postharvest treatments with salicylic acid, acetylsalicylic acid or oxalic acid delayed ripening and enhanced bioactive compounds and antioxidant capacity in sweet cherry. Journal of Agricultural and Food Chemistry, 59 (10): 5483-5489. https://doi.org/10.1021/jf200873j 
29. Vilaplana R., Valentines M. C., Toivonen P., Larrigaudiere C. 2006. Antioxidant potential and peroxidative state of 'Golden Smoothee' apples treated with 1-methylcyclopropene. Journal of the American Society for Horticultural Science, 131 (1): 104-109.

30. Wang Y., Xu F., Feng X., MacArthur R. L. 2015 (a). Modulation of Actinidia arguta fruit ripening by three ethylene biosynthesis inhibitors. Food Chemistry, 173: 405-413.

https://doi.org/10.1016/j.foodchem.2014.10.044

31. Wang Z., Ma L., Zhang X., Xu L., Cao J., Jiang W. 2015 (b). The effect of exogenous salicylic acid on antioxidant activity, bioactive compounds and antioxidant system in apricot fruit. Scientia Horticulturae, 181: 113-120. https://doi.org/10.1016/j.scienta.2014.10.055

32. Wojdyło A., Nowicka P., Oszmiański J., Golis T. 2017. Phytochemical compounds and biological effects of Actinidia fruits. Journal of Functional Foods, 30: 194-202. https://doi.org/10.1016/j.jff.2017.01.018

33. Xia Y., Chen T., Qin G., Li B., Tian S. 2016. Synergistic action of antioxidative systems contributes to the alleviation of senescence in kiwifruit. Postharvest Biology and Technology, 111: 15-24.

https://doi.org/10.1016/j.postharvbio.2015.07.026
34. Yin X. R., Zhang Y., Zhang B., Yang S. I., Shi Y. N., Ferguson I. B., Chen K. S. 2013. Effects of acetylsalicylic acid on kiwifruit ethylene biosynthesis and signalling components. Postharvest Biology and Technology, 83: 27-33. https://doi.org/10.1016/j.postharvbio.2013.03.012

35. Zhang Y., Chen K., Zhang S., Ferguson I. 2003. The role of salicylic acid in postharvest ripening of kiwifruit. Postharvest Biology and Technology, 28 (1): 67-74. https://doi.org/10.1016/S0925-5214(02)00172-2

36. Zhang Z., Huber D. J., Rao J. 2013. Antioxidant systems of ripening avocado (Persea americana Mill.) fruit following treatment at the preclimacteric stage with aqueous 1-methylcyclopropene. Postharvest Biology and Technology, 76: 58-64. https://doi.org/10.1016/j.postharvbio.2012.09.003

37. Zhu Y., Yu J., Brecht J. K., Jiang T., Zheng X. 2016. Preharvest application of oxalic acid increases quality and resistance to Penicillium expansum in kiwifruit during postharvest storage. Food Chemistry, 190: 537-543. https://doi.org/10.1016/j.foodchem.2015.06.001

38. Zorić Z., Pelaić Z., Pedisić S., Elez Garufolić L., Bursać Kovačević D., Dragović-Uzelac V. 2017. Effect of storage conditions on phenolic content and antioxidant capacity of spray dried sour cherry powder. LWT - Food Science and Technology, 79: 251-259.

https://doi.org/10.1016/j.lwt.2017.01.049

ISSN 1392-3196 / e-ISSN 2335-8947

Zemdirbyste-Agriculture, vol. 104, No. 3 (2017), p. 235-242

DOI $10.13080 / \mathrm{z}-\mathrm{a} .2017 .104 .030$

\title{
Smailialapès aktinidijos vaisių apdorojimo prieš sandèliavimą itaka vaisių kokybei juos laikant šaltai
}

\author{
J. Stefaniak, M. Sawicka, T. Krupa, P. Latocha, B. Lata \\ Varšuvos gyvybès mokslų universitetas, Lenkija
}

\section{Santrauka}

Pastaraisiais metais smailialapė aktinidija (Actinidia arguta (Siebold et Zucc.) Planch ex Miq) tapo plačiai tyrinejjama rūšimi dèl jos atsparumo žemoms temperatūroms ir didelio kiekio sveikatai naudingų biologiškai aktyvių medžiagų. Tyrimo tikslas - nustatyti oksalo, salicilo ir acetilsalicilo rūgščių, kalcio chlorido $\left(\mathrm{CaCl}_{2}\right)$ ir 1-metilciklopropeno (1-MCP) ịtaką veislès 'Weiki' aktinidijų vaisių, apdorotų prieš sandèliavimą, kokybès pokyčiams juos laikant šaltai. Per 6 sandèliavimo savaites vaisių kietumas, titruojamasis rūgštumas ir suminis askorbatu kiekis sumažèjo vidutiniškai atitinkamai nuo $61 \mathrm{~N}, 1,5 \%, 857 \mathrm{mg} \mathrm{kg}^{-1}$ iki 2,5 N, $1 \%, 380 \mathrm{mg} \mathrm{kg}$ ${ }^{1}$, o tirpiujjų kietujjų medžiagų ir suminis fenolių kiekis padidèjo vidutiniškai atitinkamai nuo $0,30 \%, 73,5 \mathrm{mg}$ $\mathrm{kg}^{-1}$ iki $0,51 \%, 172 \mathrm{mg} \mathrm{kg}^{-1}$. Apdorojimas 1-MCP pagerino vaisių kietumą ir sumažino askorbatų netekimą. Palyginus su kontroliniu variantu, vaisių kietumas ir suminis askorbatų kiekis buvo atitinkamai 50 ir $13 \%$ didesni. Vaisiuose, apdorotuose acetilsalicilo rūgštimi, smarkiai sumažèjo fenolių, palyginus su kontroliniu variantu. Suminis antioksidacinis aktyvumas esmingai nesiskyrè tarp vaisių skynimo datų, nepriklausomai nuo apdorojimo (atitinkamai 16,7 ir $17 \mathrm{mmol} \mathrm{kg}^{-1}$ skynimo metu ir sandèliavimo pabaigoje). Vaisiai, apdoroti salicilo rūgštimi, $\mathrm{CaCl}_{2}$ ir 1-MCP, pasižymèjo esmingai didesniu titruojamuoju rūgštumu, palyginus su kontroliniu variantu. Tyrimo duomenys parodè, kad laikant šaltai geriausios kokybės išliko aktinidijos vaisiai, apdoroti 1-MCP.

Reikšminiai žodžiai: Actinidia arguta, antioksidacinis potencials, askorbatas, fenoliai, mažieji kiviai, organinès rūgštys, nuskintų vaisių apdorojimas. 